\title{
ÉTUDE EXPÉRIMENTALE DE QUELQUES ASPECTS NUTHITIONNELS DE L'ASCARIDIOSE CHEZ LE PORC
}

\author{
A. RÉRAT et F. COLOMER-ROCHER \\ Station de Recherches sur l'Élevage des Porcs, \\ Centre national de Recherches zootechniques, 78 -Jouy-en-Josas \\ Institut national de la Recherche agronomique
}

\begin{abstract}
RÉSUMÉ
Le parasitisme gastro-intestinal est généralement considéré comme étant l'origine de pertes économiques importantes liées à la croissance insuffisante des animaux, au mauvais rendement de l'utilisation du régime et parfois à la mortalité qu'il provoque. On est amené à se poser la question de savoir si ces pertes peuvent être attribuées à la seule prédation parasitaire, ou si d'autres facteurs tels que des troubles fonctionnels associés à des lésions organiques peuvent être incriminés. Dans le cadre étroit de l'ascaridiose porcine, l'expérience réalisée avait pour but de préciser l'importance de la prédation parasitaire pour un degré d'infestation donné qui n'entraine pas de troubles apparents des fonctions physiologiques. La digestibilité de l'azote et de la matière sèche ainsi que la rétention ont été ainsi étudiées au cours de l'ensemble de la croissance chez trois porcs artificiellement infestés à l'aide d'œufs incubés d'A scaris suum en comparaison avec 3 animaux indemnes. Les résultats de cette expérience montrent qu'une infestation relativement peu intense ( 26 à 79 ascaris adultes présents dans le tube digestif à l'autopsie) ne provoque aucune diminution des coefficients de digestibilité et de rétention de l'azote. Il semble au contraire exister une légère tendance (non significative) à l'amélioration de ces coefficients liée peut être à un remaniement de la composition des aliments dans le tube digestif. En conclusion dans le cas d'une ascaridiose légère la prédation parasitaire semble négligeable en regard du rôle pathogène direct et indirect des parasites.
\end{abstract}

\section{SUMMARY}

EXPERIMENTAL STUDY OF SOME NUTRITIONAL ASPECTS OF ASCARIDIOSIS IN THE PIG

The gastro-intestinal parasitism generally provokes important economical losses related to insufficient growth of the animals, bad utilization of the diets and to mortality. The problem is to find out if these losses are only due to the predatory action of the parasites or of other factors such as functional disorders bound to organic lesions are involved. The aim of the experiment on pig ascaridiosis was to define more accurately the importarce of the predatory action of the parasites 
at a given degree of infestation which does not provoke obvious disorders of the physiological functions. The digestibility of nitrogen and dry matter and the nitrogen retention were studied during the whole growth period of three pigs artificially infested by incubated eggs of Ascaris suum and compared with three controls. The results of this trial show that a rather small infestation (26-79 adult ascaris in the digestive tract at the autopsy) does not provoke any decrease of the digestibility and retention coefficients of nitrogen. On the contrary there seems to be a small trend (not significant) of improvement of these coefficients perhaps depending upon a modification of the feed composition in the digestive tract. It may be concluded that in the case of a small ascaridiosis the predatory action of the parasites seems to be neglectable compared with the direct and indirect pathogen role of the parasites. 